\title{
DEPTH AND THERMAL STABILITY OF DRY ETCH DAMAGE IN GaN SCHOTTKY DIODES
}

X. A. Cao, H. Cho and S. J. Pearton

Department of Materials Science and Engineering, University of Florida, Gainesville, FL 32611

G. T. Dang, A. P. Zhang and F. Ren

Department of Chemical Engineering, University of Florida, Gainesville, FL 32611

R. J. Shul, L. Zhang and A.G. Baca

Sandia National Laboratories, Albuquerque, NM 87185

R. Hickman and J. M. Van Hove

SVT Associates, Eden Prairie, MN 55344
RECEIVED

JUL 131999

OSTI

\begin{abstract}
GaN Schottky diodes were exposed to $\mathrm{N}_{2}$ or $\mathrm{H}_{2}$ Inductively Coupled Plasmas prior to deposition of the rectifying contact. Subsequent annealing, wet photochemical etching or $\left(\mathrm{NH}_{4}\right)_{2} \mathrm{~S}$ surface passivation treatments were examined for their effect on diode currentvoltage characteristics. We found that either annealing at $750^{\circ} \mathrm{C}$ under $\mathrm{N}_{2}$, or removal of $\sim 500-600 \AA$ of the surface essentially restored the initial I-V characteristics. There was no measurable improvement in the plasma-exposed diode behavior with $\left(\mathrm{NH}_{4}\right)_{2} \mathrm{~S}$ treatments.
\end{abstract}




\section{DISCLAIMER}

This report was prepared as an account of work sponsored by an agency of the United States Government. Neither the United States Government nor any agency thereof, nor any of their employees, make any warranty, express or implied, or assumes any legal liability or responsibility for the accuracy, completeness, or usefulness of any information, apparatus, product, or process disclosed, or represents that its use would not infringe privately owned rights. Reference herein to any specific commercial product, process, or service by trade name, trademark, manufacturer, or otherwise does not necessarily constitute or imply its endorsement, recommendation, or favoring by the United States Government or any agency thereof. The views and opinions of authors expressed herein do not necessarily state or reflect those of the United States Government or any agency thereof. 


\section{DISCLAIMER}

Portions of this document may be illegible in electronic image products. Images are produced from the best available original document. 
GaN-based devices are being developed for two basic classes of applications, namely blue/green/UV emitters and high power/high temperature electronics. ${ }^{(1-5)}$ The high bond energy, $8.92 \mathrm{eV} /$ atom, of $\mathrm{GaN}$ has necessitated use of dry etching technologies for device patterning. Plasma induced damage to GaN may take several forms, all of which lead to changes in its electrical and optical properties, as follows:

1. Ion induced creation of lattice defects which generally behave as deep level states and thus produce compensation, trapping or recombination in the material. Due to channeling of the low energy ions that strike the sample, and rapid diffusion of the defects created, the effects can be measured as deep as $1000 \AA$ from the surface, even though the projected range of the ions is only $\leq 10 \AA$.

2. Unintentional passivation of dopants by atomic hydrogen. The hydrogen may be a specific component of the plasma chemistry, or may be unintentionally present from residual water vapor in the chamber or from sources such as photoresist mask erosion. The effect of the hydrogen deactivation of the dopants is a strong function of substrate temperature, but may occur to depths of several thousand angstroms.

3. Deposition of polymeric film from plasma chemistries involving $\mathrm{CH}_{\mathbf{x}}$ radicals, or from reaction of photoresist masks with $\mathrm{Cl}_{2}$-based plasma.

4. Creation of non-stoichiometric surfaces through preferential loss of one of the lattice elements. This can occur because of strong differences in the volatility of the respective etch products, leading to enrichment of the less volatile species, or by preferential sputtering of the lighter lattice element if there is a strong physical component to the etch mechanism. Typical depths of this non-stoichiometry are <100 A. 
Usikov et al. ${ }^{(6)}$ studied the effect of $\mathrm{Ar}$ and $\mathrm{Ar} / \mathrm{N}_{2}$ collimated ion beam etching on $\mathrm{GaN} p-n$ junctions. On undoped $\mathrm{GaN}$ epilayers, $\mathrm{Ar}^{+}$ion beam etching increased the nearsurface electron concentration from $10^{16} \mathrm{~cm}^{-3}$ to $10^{18} \mathrm{~cm}^{-3}$. In the PL spectrum an intense broad band appeared at $3.05 \mathrm{eV}$, and there was an increase in intensity of the yellow band at $2.20 \mathrm{eV}$. The latter is thought to involve defects such as $\mathrm{Ga}_{v}$ in some models. Use of $\mathrm{Ar}^{+} / \mathrm{N}_{2}{ }^{+}$ion beams produced less degradation of both optical and electrical properties.

Saotome at al. ${ }^{(7)}$ studied the effects of RIBE/ECR etching with pure $\mathrm{Cl}_{2}$ on $\mathrm{GaN}$ properties. Etch rates up to $\sim 1000 \AA-\mathrm{min}^{-1}$ at $500 \mathrm{~V}$ beam voltage were obtained. $\mathrm{He}-\mathrm{Cd}$ (325 nm) laser irradiation was used to measure PL from RIBE GaN samples before and after photo-assisted wet etching in an $85 \% \mathrm{KOH}: \mathrm{H}_{2} \mathrm{O}(1: 3)$ solution. The RIBE treatment decreased near band-edge PL intensity by a factor of approximately five, whereas subsequent photo-assisted wet etching restored this to about half of the original value.

Several groups have found that the n-type ohmic contact resistance was significantly improved on $\mathrm{GaN}$ if the surface were initially plasma etched, leading to a near-surface $\mathrm{N}_{2}$ deficiency and a higher n-type surface doping level. ${ }^{(8-10)}$ In contrast, Schottky contacts fabricated on reactively ion etched (RIE) $\mathrm{n}-\mathrm{GaN}$ showed severe degradation. ${ }^{(11)}$ The sheet resistance of the $\mathrm{GaN}$ below this surface region may increase substantially due to deep level creation by ion bombardment, ${ }^{(12,13)}$ while the optical properties may also be degraded. ${ }^{(14)}$

In this work, we report on a study of current-voltage (I-V) and reverse breakdown voltage $\left(\mathrm{V}_{\mathrm{B}}\right)$ characteristics in $\mathrm{GaN}$ Schottky diodes exposed to $\mathrm{H}_{2}$ or $\mathrm{N}_{2}$ Inductively Coupled Plasmas (ICP). The depth and thermal stability of the damage has been determined. 
The layer structure consisted of $0.5 \mu \mathrm{m}$ of $\mathrm{n}^{+}\left(10^{18} \mathrm{~cm}^{-3}\right) \mathrm{GaN}$ grown on a c-plane $\mathrm{Al}_{2} \mathrm{O}_{3}$ substrate, followed by $3 \mu \mathrm{m}$ of nominally undoped $\left(\mathrm{n} \sim 10^{17} \mathrm{~cm}^{-3}\right) \mathrm{GaN}$. The samples were grown by rf plasma-assisted Molecular Beam Epitaxy. ${ }^{(15)}$ Ohmic contacts were formed with $\mathrm{Ti} / \mathrm{Au}$ annealed at $600^{\circ} \mathrm{C}$. The exposed $\mathrm{GaN}$ surface was then exposed to ICP $\mathrm{H}_{2}$ or $\mathrm{N}_{2}$ discharges, and either annealed or photoelectrochemically etched in 0.2 $\mathrm{M} \mathrm{KOH}$ solutions prior to deposition of the Pt/Au Schottky contacts through a stencil mask. The diameter of these contacts was $250 \mu \mathrm{m}$. In some case a mesa structure was formed by $\mathrm{Cl}_{2} / \mathrm{Ar} \mathrm{ICP}$ etching down to the $\mathrm{n}^{+}-\mathrm{GaN}$ layer, followed by $750{ }^{\circ} \mathrm{C}$ annealing to remove etch damage. These samples were then treated in $\left(\mathrm{NH}_{4}\right)_{2} \mathrm{~S}$ solution at $25^{\circ} \mathrm{C}$ for 20 mins. ${ }^{(16)}$ Schematics of the planar and mesa diodes are shown in Figure 1.

The typical effect of either $\mathrm{H}_{2}$ or $\mathrm{N}_{2}$ plasma exposure was a severe decrease in reverse breakdown voltage and much more forward leakage current as the barrier height $\left(\Phi_{B}\right)$ was decreased. An example is shown in Figure 2, where $V_{B}$ decreases from $-5 \mathrm{~V}$ to approximately $-1 \mathrm{~V}$ after exposure to a $500 \mathrm{~W}$ source power, $150 \mathrm{~W}$ rf chuck power (dc self-bias $-221 \mathrm{~V}$ ), $5 \mathrm{mTorr} \mathrm{N}_{2}$ discharge. Under similar plasma conditions we always observed somewhat worse degradation of diode properties with $\mathrm{N}_{2}$ compared to $\mathrm{H}_{2}$ discharges, probably due to the greater mass of the impinging $\mathrm{N}_{2}{ }^{+}$ions.

As the samples were annealed for 30 secs under a 1 atm $N_{2}$ ambient at different temperatures, there was significant improvement in the I-V characteristics, as also shown in Figure 2. However at $850^{\circ} \mathrm{C}$, the quality of the diode behavior began to degrade. This has been ascribed to the onset of preferential $\mathrm{N}_{2}$ loss from the $\mathrm{GaN}$ surface, which requires use of a stable encapsulating layer such as AlN to prevent. ${ }^{(17)}$ Figure 3 shows the variation of $V_{B}$ with annealing temperature - clearly at $750{ }^{\circ} \mathrm{C}$ there is almost complete restoration of the initial $V_{B}$ value. 
A similar set of I-V characteristics were recorded for diodes in which we removed various amount of the plasma-damaged surface by photochemical etching ${ }^{(18)}$ prior to deposition of the Schottky contact. Figure 3 also shows the variation of $V_{B}$ with depth removed for samples exposed to the same discharge as in the annealing experiments $\left(\mathrm{N}_{2}\right.$, $500 \mathrm{~W}$ source power, $150 \mathrm{~W}$ rf chuck power, $5 \mathrm{mT}$ Torr). After removal of $\sim 250 \AA$, the $V_{B}$ value is restored to about half of its initial value. For larger removal depths it becomes increasingly difficult to accurately measure the etch depth because of the surface roughening typical of PEC etching, but we estimated that $500-600 \AA$ of $\mathrm{GaN}$ must be removed to completely restore $V_{B}$.

Figure 4 shows I-V characteristics from control and $\left(\mathrm{NH}_{4}\right)_{2} \mathrm{~S}$ treated mesa diodes. For diodes not exposed to the ICP discharges, there was little improvement in $V_{B}$ (Figure 4), but the forward section of the I-V characteristic showed a decrease in ideality factor (Figure 5). Note that the $2 \mathrm{kT}$ leakage current in a diode of this type has contributions from both the bulk space-charge region and the mesa surface, and that sulfide passivation would only affect the latter. On diodes damaged by plasma exposure, we did not observe any improvement in $\mathrm{I}-\mathrm{V}$ characteristics with the $\left(\mathrm{NH}_{4}\right)_{2} \mathrm{~S}$ treatment. In this case the diode behavior is clearly dominated by the $500-600 \AA$ thick damaged region and not by the surface recombination velocity.

In summary, the Schottky diode characteristics of ICP plasma exposure GaN were investigated. The main conclusions of the study are:

1. $\mathrm{N}_{2}$ discharges produce more degradation in $\mathrm{V}_{\mathrm{B}}$ than $\mathrm{H}_{2}$ discharges, which implicates ion mass as the main factor.

2. The electrical damage depth is $500-600 \AA$. 
3. The diode characteristics are almost restored by post-plasma annealing at $750{ }^{\circ} \mathrm{C}$. Higher annealing temperatures produce degraded I-V properties due to $\mathrm{N}_{2}$ loss.

4. $\left(\mathrm{NH}_{4}\right)_{2} \mathrm{~S}$ passivation is relatively ineffective on $\mathrm{GaN}$, and has no effect on plasma damaged material.

\section{ACKNOWLEDGEMENTS}

The work at UF is partially supported by a DARPA/EPRI grant, no. MDA 972-98-10006 (D. Radack and J. Melcher) monitored by ONR (J. C. Zolper), and a NSF grant DMR 97-32865 (L. D. Hess). Sandia is a multiprogram laboratory operated by Sandia Corporation, a Lockheed-Martin company, for the US Department of Energy under contract no. DEAC04-94-AL-85000. 


\section{References}

1. See for example, GaN and Related Materials, ed. S. J. Pearton (Gordon and Breach, NY, 1997); GaN, ed. J. I Pankove and T. D. Movstakas (Academic Press, San Diego, 1998).

2. S. Nakahama, IEEE J. Selected Topics in Quantum Electronics, 4483 (1998).

3. S. Nakamura and G. Fasol, The Blue Laser Diode (Springer, Berlin 1998).

4. S. N. Mohammad and H. Morkoc, Prog. Quantum Electron. 20361 (1996).

5. F. A. Ponce and D. P. Bour, Nature $\underline{386} 351$ (1997).

6. A. S. Usikov, W. L. Lundin, U. I. Ushakov, B. V. Pushnyi, N. M. Schmidt, Y. M. Zadiranov and T. V. Shubtra, Proc. ECS 98-14, 57 (1998)

7. K. Satore, A. Matsutani, T. Shirasawa, M. Mori, T. Honda, T. Sakaguchi, F. Koyama and K. Iga, Mat. Res. Soc. Symp. Proc. 4491029 (1997).

8. Z. F. Fan, S. N. Mohammad, W. Kim, Ö. Aktas, A. E. Botchkarev and H. Morkoç, Appl. Phys. Lett. $\underline{69} 1672$ (1996).

9. A. T. Ping, Q. Chen, J. W. Yang, M. A. Khan and I. Adesida, J. Electron. Mater. 27 261 (1998).

10. J. Y. Chen, C. J. Pan and G. C. Chi, Solid-State Electron. 43649 (1999).

11. A. T. Ping, A. C. Schmitz, I. Adesida, M. A. Khan, Q. Chen and J. W. Yang, J. Electron. Meter. 26266 (1997).

12. S. J. Pearton, J. W. Lee, J. D. MacKenzie, C. R. Abernathy and R. J. Shul, Appl. Phys. Lett. $\underline{67} 2329$ (1995).

13. C. R. Eddy, Jr. and B. Molnar, Mat. Res. Soc. Symp. Proc. 395745 (1996). 
14. R. J. Shul, J. C. Zolper, M. H. Crawford, R. J. Hickamn, R. D. Briggs, S. J. Pearton, J. W. Lee, R. F. Karlicek Jr., C. Tran, M. Schurman, C. Constantine and C. Barratt, Proc. Electrochem. Soc. 96-15 232 (1996).

15. J. M. Van Hove, R. Hickman, J. J. Klaassen, P. P. Chow and P. P. Ruden, Appl. Phys. Lett. $\underline{70} 282$ (1997).

16. V. Malhotra and C. W. Wilmsen, in Handbook of Compound Semiconductors, ed. P. H. Holloway and G. E. McGuire (Noyes Publications, Park Ridge, NJ 1995).

17. J. C. Zolper, D. J. Rieger, A. G. Baca, S. J. Pearton, J. W. Lee and R. A. Stall, Appl. Phys. Lett. $\underline{69} 538$ (1996).

18. C. Youtsey, G. Bulman and I. Adesida, J. Electron. Meter. 27282 (1998). 


\section{Figure Captions}

Figure 1. Schematic of the planar (top) and mesa (bottom) diodes.

Figure 2. I-V characteristics from $\mathrm{GaN}$ planar diodes before and after ICP $\mathrm{N}_{2}$ plasma exposure ( $500 \mathrm{~W}$ source power, $150 \mathrm{~W}$ rf chuck power, $5 \mathrm{mTorr}$ ), and after subsequent annealing at different temperatures.

Figure 3. Variation of $V_{B}$ in $N_{2}$ plasma exposed ( $500 \mathrm{~W}$ source power, $150 \mathrm{~W}$ rf chuck power, $5 \mathrm{mTorr}$ ) GaN planar diodes as a function of either annealing temperature (top) or depth of damaged material removed (bottom).

Figure 4. I-V characteristics from $\mathrm{GaN}$ mesa diodes before and after $\left(\mathrm{NH}_{4}\right)_{2} \mathrm{~S}$ treatment.

Figure 5. Forward I-V characteristics from $\mathrm{GaN}$ mesa diodes before and after $\left(\mathrm{NH}_{4}\right)_{2} \mathrm{~S}$ treatment. Ideality factors are $\sim 2.3$ and 1.7 , respectively. 


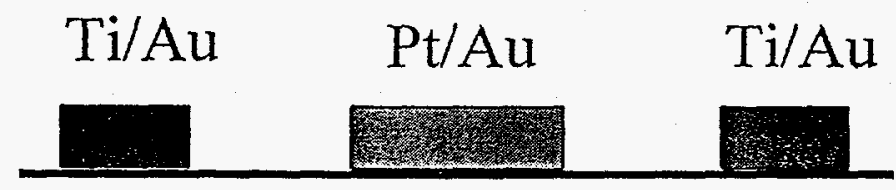

$3 \mu \mathrm{m}$ undoped $\left(\mathrm{n} \sim 10^{17} \mathrm{~cm}^{-3}\right) \mathrm{GaN}$
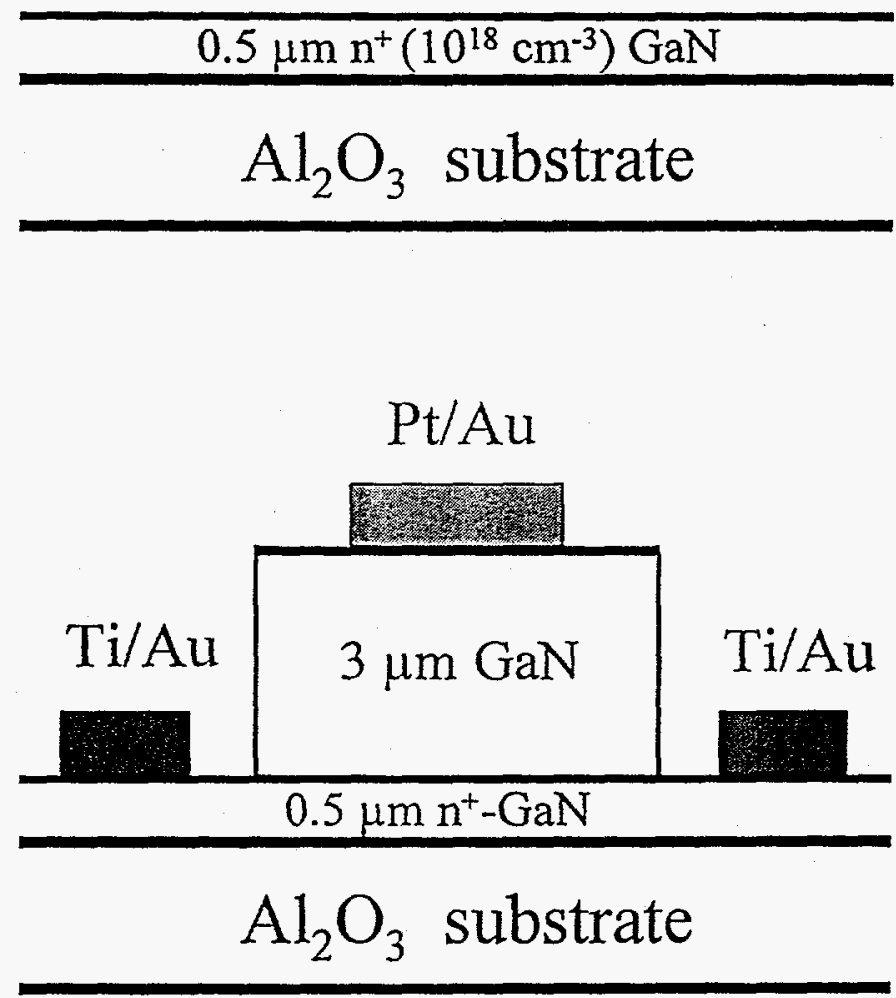


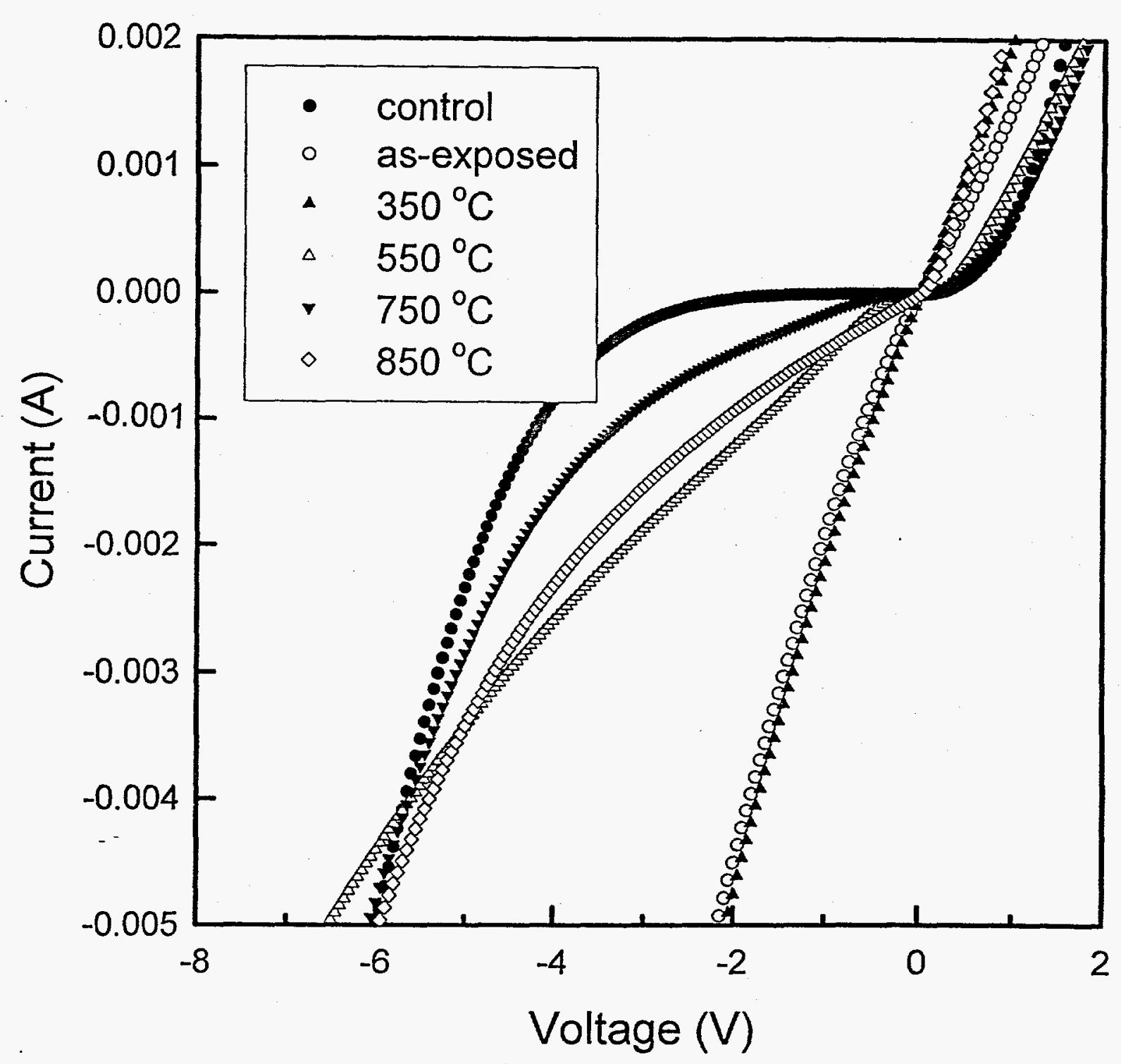



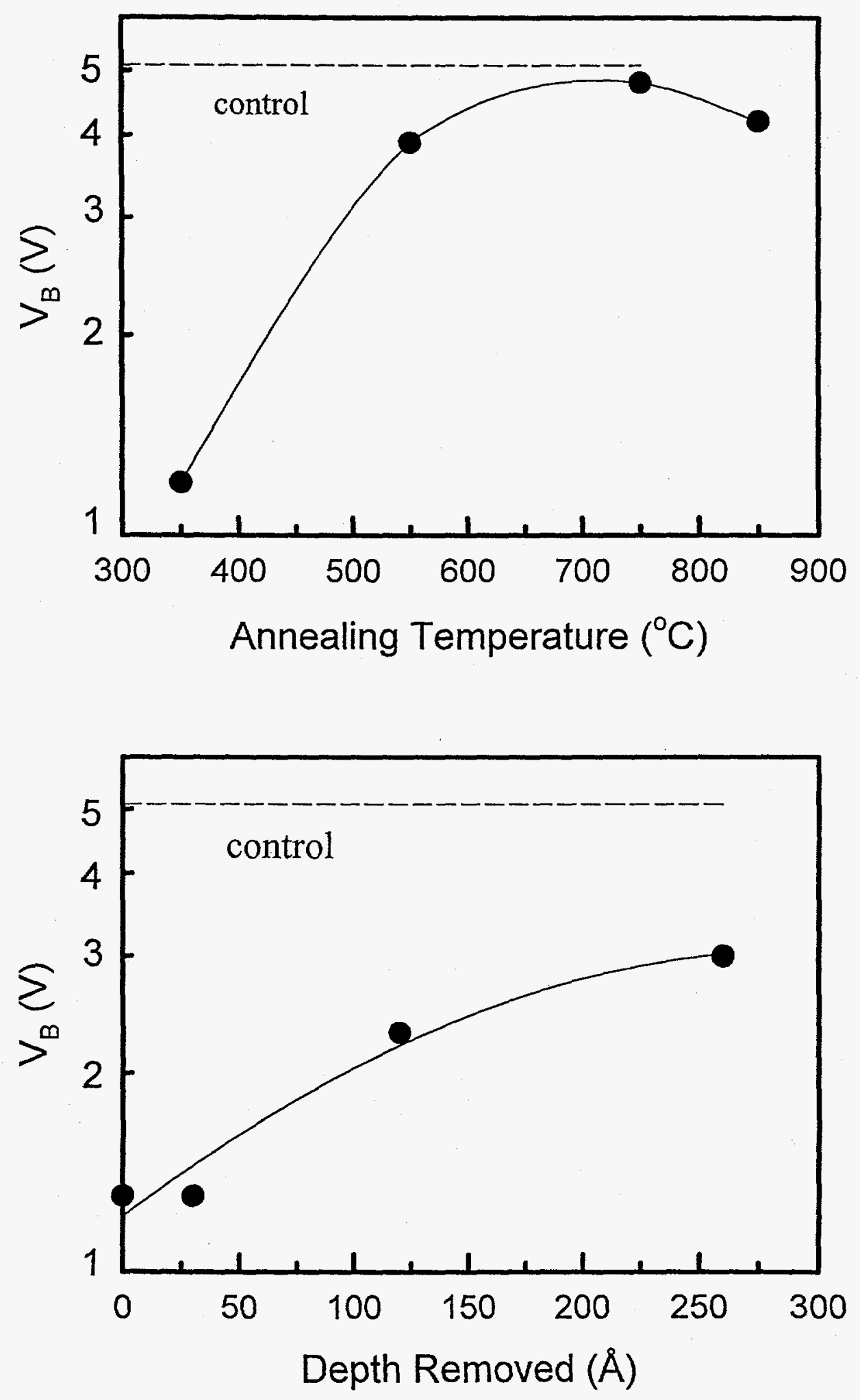


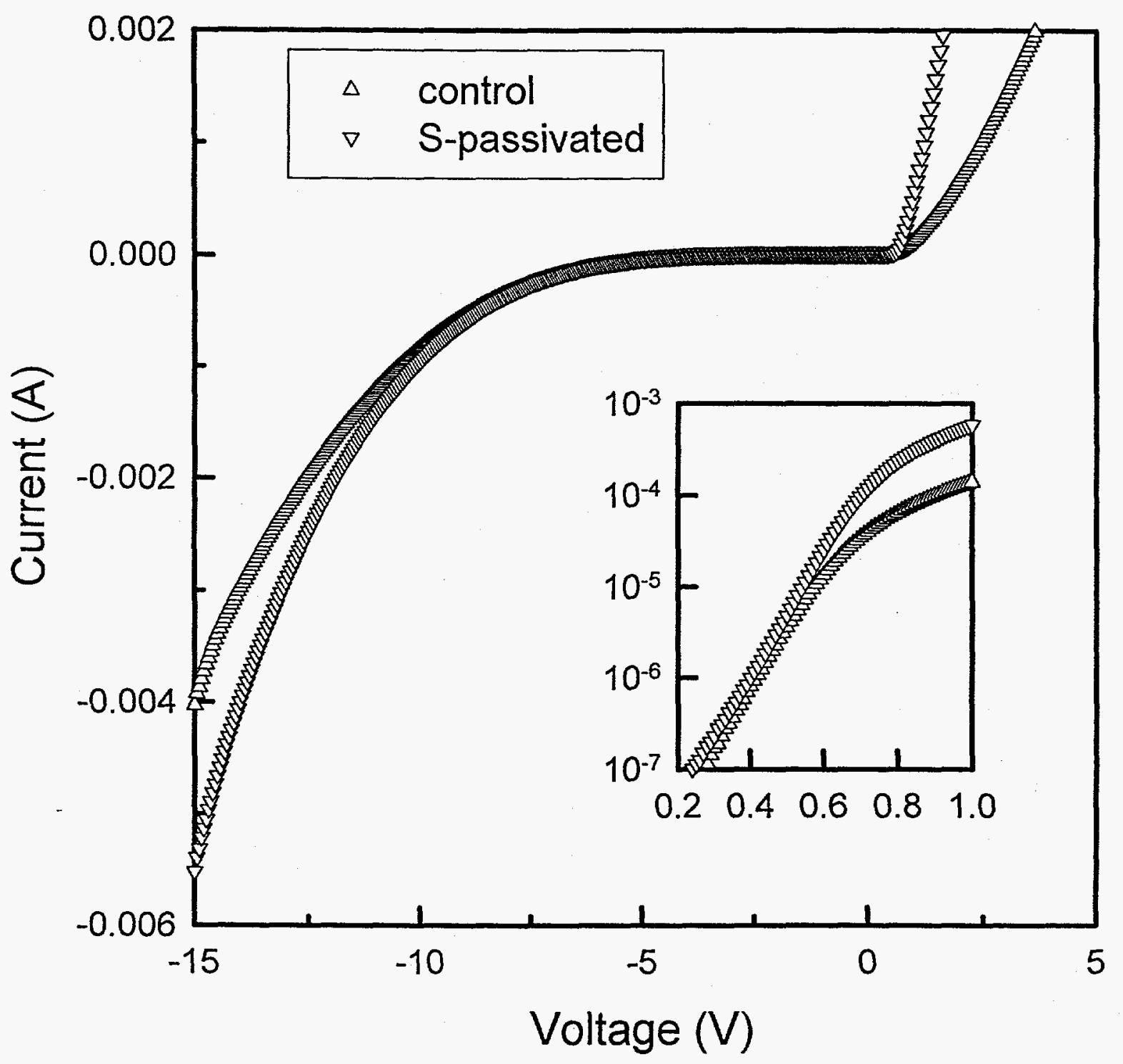




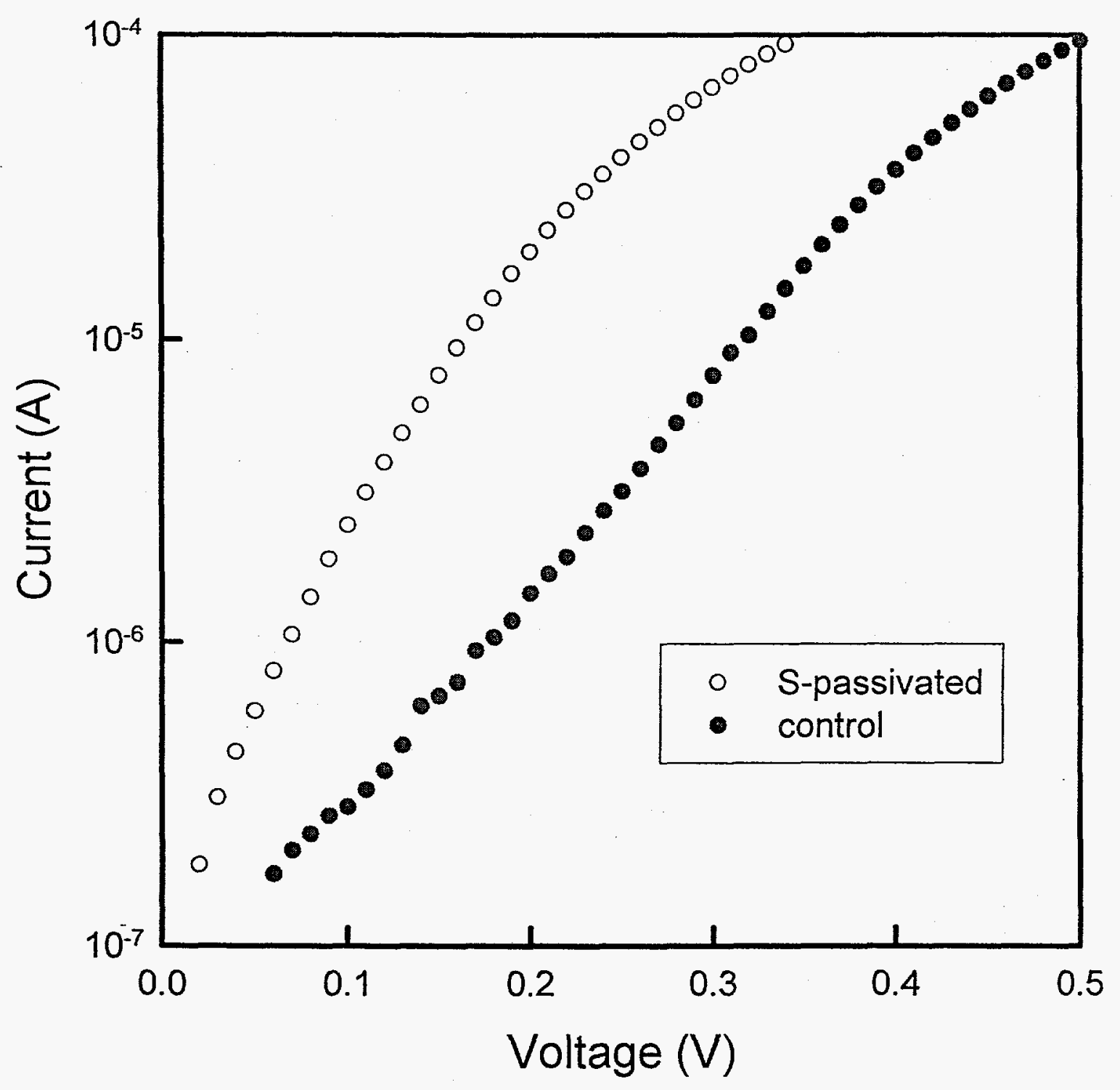

